\title{
Rectal perforation caused by a self-inserted foreign body: a case report
}

\section{R. Sanjay*, Rajendra Bagree, Pradeep Panwar, Prashant Kumar}

Department of General surgery, Sawai Mansingh Medical College, Jaipur, Rajasthan, India

Received: 13 July 2021

Revised: 18 August 2021

Accepted: 21 August 2021

\author{
*Correspondence: \\ Dr. R. Sanjay, \\ E-mail: sanjay888r@gmail.com
}

Copyright: (C) the author(s), publisher and licensee Medip Academy. This is an open-access article distributed under the terms of the Creative Commons Attribution Non-Commercial License, which permits unrestricted non-commercial use, distribution, and reproduction in any medium, provided the original work is properly cited.

\begin{abstract}
Rectal foreign bodies have a storied history as a part of anorectal trauma. Objects encountered are most commonly household objects consisting of bottles and glasses. Other objects include tooth brushes, deodorant bottles, food articles, knives, sports equipment, cell phones, flash lights, wooden rods, broom sticks, sex toys including dildos and vibrators, light bulbs, nails, or other construction tools, christmas ornaments, aerosol canisters, cocaine packets, and many more. The reasons for insertion in decreasing order of frequency are autoeroticism, concealment, attention-seeking behavior, accidental, assault and to alleviate constipation. Here we presented a case of 32 years old presented to the ER with complaints of pain in lower abdomen and anal region for 12 hours. He complained of severe pain when he tried to defecate. He gave history of self-insertion of an empty drug vial into his rectum. Rectal foreign bodies represent a challenging and unique field of colorectal trauma. The important factors in dealing with these patients are careful history and physical examination. Patients are often embarrassed about this condition and may conceal the truth. So, a high index of suspicion is required to accurately diagnose.
\end{abstract}

Keywords: Rectal foreign bodies, Rectal perforation peritonitis, Rectal trauma

\section{INTRODUCTION}

Rectal foreign bodies have a storied history as a part of anorectal trauma. The mean age at presentation is 44 years, but ranges from 20 to over $90 .^{1-4}$ with a decidedly higher proportion of male patients $(17-37: 1) .^{1,5}$

The types of foreign body vary widely, as do the reasons for insertion. Objects encountered are most commonly household objects consisting of bottles and glasses (42.2\%). Other objects include tooth brushes, deodorant bottles, food articles, knives, sports equipment, cell phones, flash lights, wooden rods, broom sticks, sex toys including dildos and vibrators, light bulbs, nails, or other construction tools, christmas ornaments, aerosol canisters, cocaine packets, and many more.

The reasons for insertion in decreasing order of frequency are autoeroticism, concealment, attention-seeking behavior, accidental, assault and to alleviate constipation. ${ }^{4}$ Some patients present immediately upon recognition of the inability to remove the object, whereas others may wait upto 2 weeks after insertion to present for evaluation. ${ }^{6}$

Here we report a case of a 32 years old male who inserted an empty injection vial in his rectum which broke into pieces and perforated his rectum. With increasing incidence of different improvised objects for sexual arousal, surgeons must be well informed about the approach to management of patients with foreign body in rectum and its complications.

\section{CASE REPORT}

A 32 years old presented to the ER with complaints of pain in lower abdomen and anal region for 12 hours. He complained of severe pain when he tried to defecate. He gave history of self-insertion of an empty drug vial into his rectum. There were no signs and symptoms of abdominal distension, vomiting, bleeding per rectum or any urinary symptoms. He had inserted the vial around 2 days ago and attempted to remove it by himself but failed. He was 
embarrassed about it and he tried to conceal the truth. When he presented to the ER his vitals were stable. Pulse rate recorded around 86 beats per minute, blood pressure was around 140/90 $\mathrm{mmHg}$ and oxygen saturation was $99 \%$. On palpation, there were no signs of peritonitis, no guarding, no rigidity. Abdomen was soft and non-tender. On per rectal digital examination, anal tone was normal. There was no active bleeding and the foreign body was not palpable.

Radiograph of the chest and abdomen in erect posture was performed which showed crescent shaped gas shadow under the right dome of diaphragm suggestive of hollow viscus perforation (Figure 1 and 2). X-ray bilateral hip with pelvis was also done which confirmed the presence of a foreign body (Figure 3).

The patient was shifted to the operating room. Under general anesthesia, abdomen was opened in lower midline. There was a $4 \times 2 \mathrm{~cm}$ perforation in the rectum through which pieces of glass were visible (Figure 4 ). They were removed and the gut was traced proximally. Around $10 \mathrm{~cm}$ proximal to the perforation site the remaining pieces of foreign body were palpable. Enterotomy was done and remaining glass pieces were removed (Figure 5).

Both the perforation site and enterotomy site were repaired primarily and closed. The patient was kept on intravenous antibiotics till fifth postoperative day. He was allowed to take oral sips on third post-operative day. He passed motion on the fourth post-operative day. He was discharged on the sixth post-operative day when he was tolerating oral feeds and had no complaints. Psychiatric consultation was also arranged for the patient. On followup after one week the patient had no complaints, the surgical wound site had healed properly with no complications.

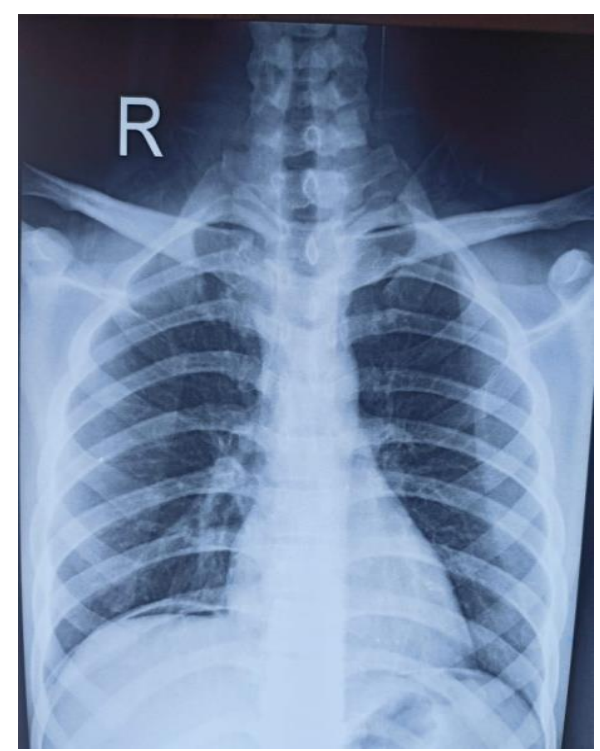

Figure 1: Plain chest $X$-ray in erect position showing crescentic gas shadow below the right dome of diaphragm.

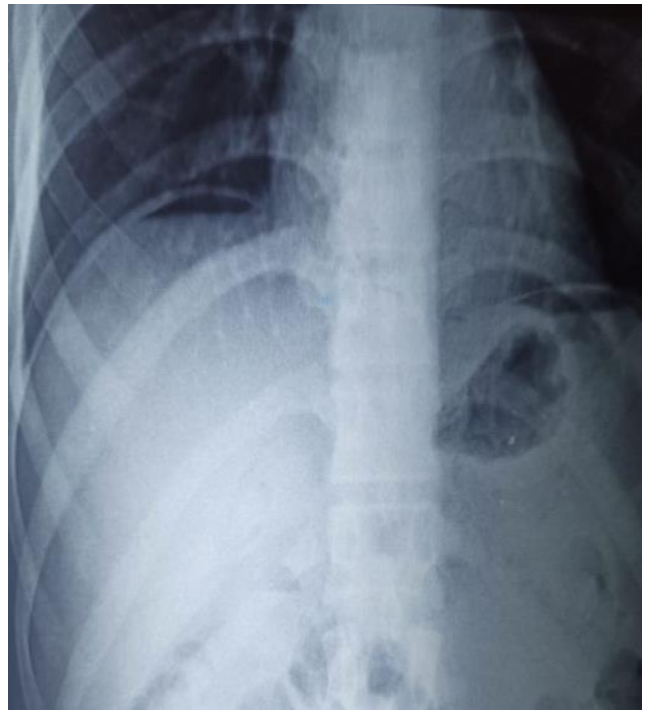

Figure 2: Plain X-ray of abdomen erect showing crescentic gas shadow below the right dome of diaphragm.

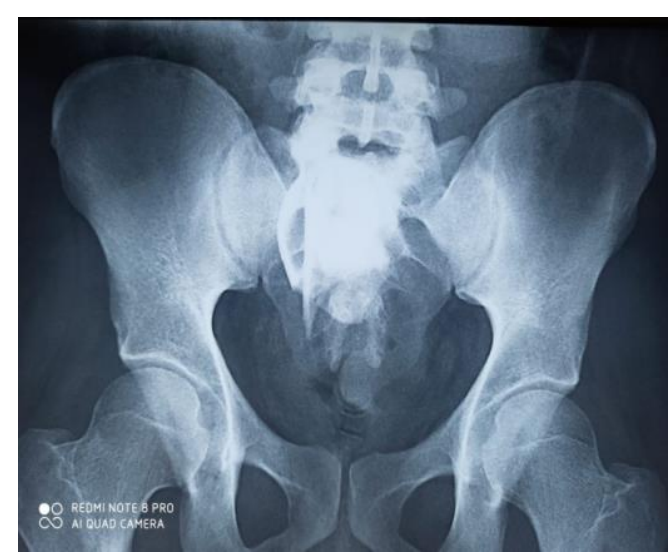

Figure 3: X-ray bilateral hip with pelvis showing location of the foreign body.

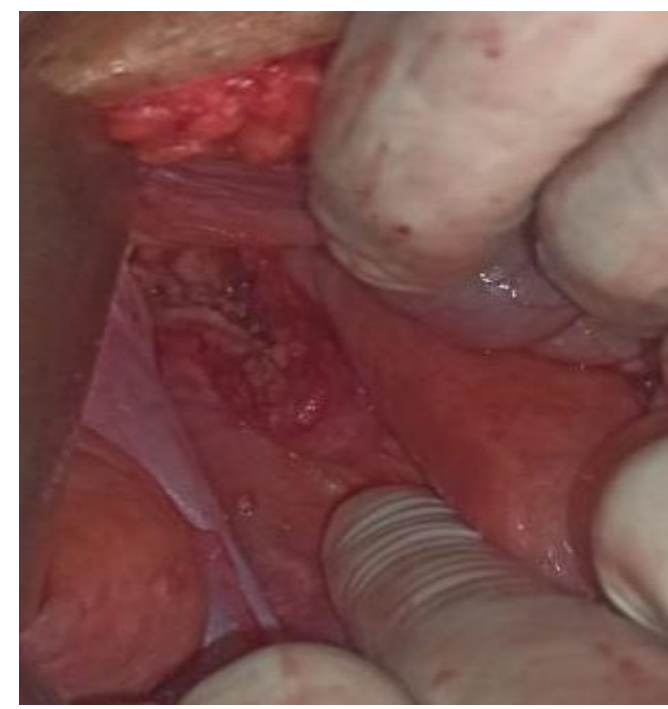

Figure 4: A $4 \times 2 \mathrm{~cm}$ size perforation in anterior surface of rectum. 


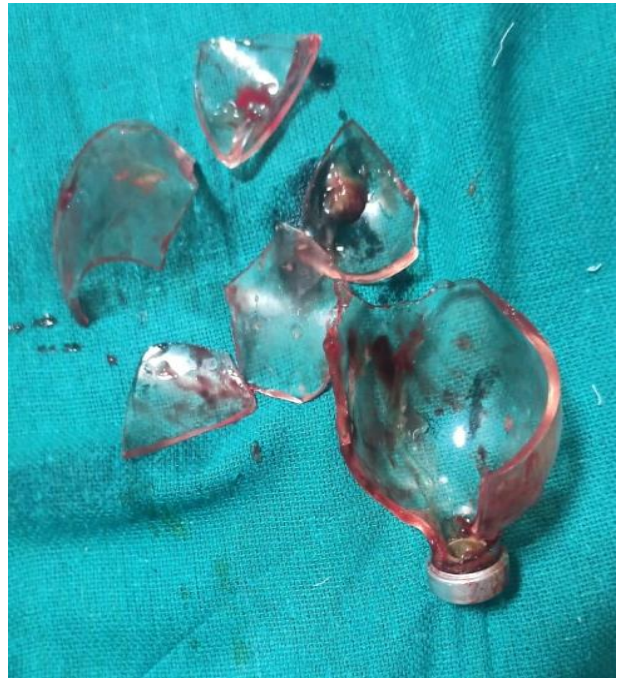

Figure 5: Retrieved foreign body, broken drug vial, which caused the rectal perforation.

\section{DISCUSSION}

Patients with rectal foreign bodies are often embarrassed about their condition and may seek to conceal the true nature of their visit to the emergency room. A high index of suspicion is required to accurately diagnose their condition. At the same time, the practitioner needs to maintain utmost degree of professionalism. One must remember that these objects may be inserted under duress, as a means of assault, or as a manifestation of psychiatric disorder. It is essential to be non-threatening and nonjudgmental, despite the fact that their initial history may be fabricated. Once the foreign body is effectively managed, arrangements can be made for psychiatric evaluation and treatment as needed.

Common presenting complaints include rectal or abdominal pain, constipation or obstipation, bright red blood per rectum or incontinence. ${ }^{1}$ The first step in evaluation of a patient should be assessment for peritonitis, as this requires urgent laparotomy and suggests a perforation with intraperitoneal contamination. If there is any question, an abdominal series or upright abdominal radiograph can reveal can reveal the presence of free air and location of the object relative to the pelvic floor. A careful digital rectal examination is the most informative component of the evaluation process, as it indicates the proximity of the object to the pelvic floor. It is essential to also evaluate and document the functional status of the sphincter complex both by examination and clinical history. Incontinence may be associated with sphincter damage from either the trauma of insertion or removal of object. $^{7}$ The American Association of the Surgery of Trauma rectum injury scale may be used to assess injury from rectal foreign body.

There are a large variety of described extraction techniques; generally, one should proceed from the least invasive to the most invasive means of extraction. Unless signs of peritonitis are present, which necessitate emergency laparotomy, an attempt at bedside extraction in the emergency department should always be made. This is successful in removing the foreign body in 60 to $75 \%{ }^{6,9,10}$ Patients should be positioned in the lithotomy position with reverse trendelenburg angulation. A perianal block should be performed with a local anesthetic if the object is not readily extractable. This can be supplemented with the use of conscious sedation using fentanyl, propofol or ketamine. This aids in full relaxation of the patient's abdominal wall musculature and anal sphincter muscles, which is important for successful extraction.

Suprapubic or sigmoid pressure applied by assistant helps move the object caudally and prevents cephalad migration. Sharp objects should not be grasped by this route and should prompt use of endoscopic techniques or other tools. ${ }^{11}$ If the object is not within reach for removal by hand or instruments, rigid or flexible sigmoidoscopy should be performed to visualize and attempt extraction. When the object is visualized through the scope, a polypectomy snare may be used to 'lasso' the foreign body for extraction. ${ }^{5}$ Biopsy forceps through a rigid endoscope can be used. A guide wire and balloon dilator may be used to inflate a $40 \mathrm{~mm}$ balloon proximal to the object. ${ }^{12}$

If the above techniques are not successful, the patient requires surgical approach. A laparoscopic- assisted technique, where object can be milked inferiorly with direct intraabdominal visualization using laparoscope and grasper to allow transanal extraction. ${ }^{13}$ Similarly, a lower midline minilaparotomy may be used to directly squeeze the rectum and allow transanal removal. Finally, if none of these techniques work, a colotomy with transabdominal removal may be required. This is also the technique usually required in an emergent setting where perforation has occurred. If tissue quality is good, a primary repair or short segment resection may be performed. ${ }^{14,15}$

Table 1: Rectum injury scale of the American association for the surgery of trauma. ${ }^{8}$

\begin{tabular}{|c|c|c|}
\hline Grade & Lesion & Description \\
\hline 1 & $\begin{array}{l}\text { Hematoma or } \\
\text { laceration }\end{array}$ & $\begin{array}{l}\text { Contusion or hematoma without devascularisation. Partial thickness laceration of } \\
\text { wall }\end{array}$ \\
\hline 2 & Laceration & Full thickness laceration of wall that compromises $<50 \%$ of circumference \\
\hline 3 & Laceration & Full thickness laceration of wall that compromises $>50 \%$ of circumference \\
\hline 4 & Laceration & Full thickness laceration of wall that extends into the perineum \\
\hline 5 & Vascular & Devascularised segment of rectum \\
\hline
\end{tabular}




\section{CONCLUSION}

Rectal foreign bodies represent a challenging and unique field of colorectal trauma. The important factors in dealing with these patients are careful history and physical examination. Patients are often embarrassed about this condition and may conceal the truth. So, a high index of suspicion is required to accurately diagnose. Evidence of perforation needs emergent laparotomy. After thorough evaluation of the patient, the appropriate technique for extraction of foreign body should be decided. Psychiatric evaluation of the patients should be done to prevent further incidents.

Funding: No funding sources

Conflict of interest: None declared

Ethical approval: Not required

\section{REFERENCES}

1. Kurer MA, Davey C, Khan S, Chintapatla S. Colorectal foreign bodies: a systematic review. Colorectal Dis. 2010;12(9):851-61.

2. Ooi BS, Ho YH, Eu KW, Nyam D, Leong A, Choen F. Management of anorectal foreign bodies: a cause of obscure anal pain. Aust N Z J Surg. 1998;68(12):852-5.

3. Hermosa JI, Cazador A, Ruiz B, Sirvent JM, Roig J, Farres R. Management of foreign bodies in the rectum. Colorectal Dis. 2007;9(6):543-8.

4. Clarke DL, Buccimazza I, Anderson FA, Thomson SR. Colorectal foreign bodies. Colorectal Dis. 2005;7(1):98-103.

5. Goldberg JE, Steele SR. Rectal foreign bodies. Surg Clin North Am. 2010;90(1):173-84.

6. Lake JP, Essani R, Petrone P, Kaiser AM, Asensio J, Beart RW. Management of retained colorectal foreign bodies: predictors of operative intervention. Dis Colon Rectum. 2004;47(10):1694-8.
7. Crass RA, Tranbaugh RF, Kudsk KA, Trunkey DD. Colorectal foreign bodies and perforation. Am J Surg. 1981;142(1):85-8.

8. Moore EE, Cogbill TH, Malangoni MA, Jurkovich GJ, Champion HR, Gennarelli TA, et al. Organ injury scaling, II: Pancreas, duodenum, small bowel, colon, and rectum. J Trauma. 1990;30(11):1427-9.

9. Barone JE, Yee J, Nealon TF. Management of foreign bodies and trauma of the rectum. Surg Gynecol Obstet. 1983;156(4):453-7.

10. Cohen JS, Sackier JM. Management of colorectal foreign bodies. J R Coll Surg Edinb. 1996;41(5):3125 .

11. Sharma H, Banka S, Walton R, Memon MA. A novel technique for nonoperative removal of round rectal foreign bodies. Tech Coloproctol. 2007;11(1):58-9.

12. Billi P, Bassi M, Ferrara F, Biscardi A, Villani S, Baldoni F, et al. Endoscopic removal of a large rectal foreign body using a large balloon dilator: report of a case and description of the technique. Endoscopy. 2010;42(2):238.

13. Berghoff KR, Franklin ME. Laparoscopic-assisted rectal foreign body removal: report of a case. Dis Colon Rectum. 2005;48(10):1975-7.

14. Demetriades D, Murray JA, Chan L, Committee on Multicenter Clinical Trials, American Association for the Surgery of Trauma. Penetrating colon injuries requiring resection: diversion or pri- mary anastomosis? An AAST prospective multicenter study. J Trauma 2001;50(5):765-5.

15. Herr MW, Gagliano RA. Historical perspective and current management of colonic and intraperitoneal rectal trauma. Curr Surg. 2005;62(2):187-92.

Cite this article as: Sanjay R, Bagree R, Panwar P, Kumar P. Rectal perforation caused by a self-inserted foreign body: a case report. Int Surg J 2021;8:2803-6. 